środowisk naukowych polskich i z krajów sąsiednich oraz fakt interdyscyplinarności obrad, wśród prelegentów byli bowiem historycy wychowania, historycy, socjologowie, pedagogowie i literaturoznawcy. Z przyczyn losowych na obrady nie zdołała dotrzeć część prelegentów, ich wystąpienia zostaną jednak dołączone do materiałów konferencji, które ukażą się drukiem.

Krzysztof Ratajczak

\title{
Międzynarodowa konferencja ,Szkolnictwo pijarskie w czasach minionych a współczesne problemy edukacji historycznej". (Kazimierz Dolny 15-17 X 2007)
}

W dniach 15-17 października 2007 r. w Kazimierzu Dolnym odbyła się międzynarodowa konferencja naukowa pt. „Szkolnictwo pijarskie w czasach minionych a współczesne problemy edukacji historycznej". Została ona zorganizowana przez Zakład Dydaktyki Historii UMCS w Lublinie wraz z Polską Prowincją Zakonu Pijarów w związku z przypadającą w 2007 r. 450 rocznicą urodzin św. Józefa Kalasancjusza, twórcy pierwszej w Europie szkoły powszechnej oraz założyciela zakonu pijarów. Dodatkową motywacją do organizacji konferencji było ogłoszenie roku 2007 przez ministra edukacji narodowej Rokiem św. Józefa Kalasancjusza.

Uczestnikami zjazdu byli przedstawiciele polskich ośrodków akademickich z Warszawy, Gdańska, Bydgoszczy, Wrocławia, Opola, Katowic, Krakowa, Rzeszowa, Zielonej Góry, Torunia i Lublina. Na konferencję przybyli także goście zagraniczni z Czech i Słowacji zajmujący się działalnością oświatową i kulturalną zakonu pijarów oraz problemami współczesnej dydaktyki.

Spotkanie zainaugurował dziekan Wydziału Humanistycznego UMCS, prof. Henryk Gmiterek oraz przedstawiciel organizatorów prof. Krystyna Wróbel-Lipowa. Obrady rozpoczęła sesja plenarna, której przewodniczyli prof. Lech Mokrzecki, prof. Janusz Rulka i o. dr Henryk Bogdziewicz SP. Na początku o. Edwarda Kryściaka z Polskiej Prowincji Zakonu Pijarów przedstawił sylwetkę św. Józefa Kalasancjusza. Przypomniano także postać i działalność najwybitniejszego przedstawiciela zakonu pijarów w Polsce ks. S. Konarskiego. Prof. Czesław Nowarski zaprezentował poglądy ks. S. Konarskiego na temat kształcenia i wychowania młodzieży, podkreślając ich aktualność. Natomiast prof. Krystyna Wróbel-Lipowa przybliżyła działalność Collegium Nobilium za czasów S. Konarskiego jako szkoły służącej wychowaniu patriotycznemu i obywatelskiemu. W szeroką problematykę historii wychowania jako przedmiotu kształcenia pedagogicznego wprowadzili uczestników konferencji profesorowie Wiesław Jamrożek i Krzysztof Jakubiak, przedstawiając tradycje nauczania tego przedmiotu, stan obecny i jego przyszłość.

Następnie uczestnicy udali się do Opola Lubelskiego - miejscowości związanej z działalnością zakonu pijarów w XVIII-XIX w. Tutaj po uroczystej mszy św. odprawionej przez ojców pijarów oraz zwiedzeniu kościoła popijarskiego, kontynuowano obrady 
w dawnym budynku pijarskiej szkoły rzemieślniczej (Gimansium Artificum). Tej części obrad plenarnych przewodniczyli: prof. Maria Kujawska, prof. Krzysztof Jakubiak oraz prof. ph. dr Jaroslav Vaculik. Jej tematyka związana była $\mathrm{z}$ działalnością zakonu pijarów na terenach Rzeczypospolitej oraz w Opolu Lubelskim i na Lubelszczyźnie. O związkach pijarów z Opolem mogliśmy się dowiedzieć z wystąpień mgr. Huberta Mącika, który mówił o założeniach architektonicznych oraz przeszłości budynku szkoły rzemieślniczej w Opolu Lubelskim oraz dr. Mariusza Ausza prezentującego działalność edukacyjną pijarów w tym mieście. Natomiast dr Marzena Okrasa w swoim wystąpieniu przedstawiła funkcję opiekuńczo-wychowawczą zakonu pijarów na Lubelszczyźnie do 1832 r. Następny z prelegentów - dr Józef Świeboda podjął próbę przedstawienia problematyki nawiązywania do rodowodu pijarskiego przez szkoły współcześnie działające w Polsce. Profesor Roman Pelczar zaprezentował stan szkolnictwa pijarskiego na południowo-wschodnich terenach Rzeczypospolitej w XVII i XVIII w. Natomiast dr Kazimierz Puchowski zajął się sprawą edukacji elit w pijarskim Collegium Nobilium we Lwowie opierając się na materiale źródłowym. Pani prof. dr hab. Maria Kujawska zaprezentowała zmiany w oświacie polskiej w ciągu ostatnich kilkunastu lat, kładąc nacisk na innowacje i eksperymenty pedagogiczne w szkolnictwie polskim 1989-2006.

Podczas drugiego dnia obrad uczestnicy zostali podzieleni na trzy sekcje. Sekcja I, której przewodniczyli prof. Grażyna Pańko, prof. Anna Glimos-Nadgórska i o. Edward Kryściak SP zajęła się kwestiami dotyczącymi zmian we współczesnej edukacji historycznej, jeśli chodzi o treści nauczania zarówno w Polsce, jak i Czechach. Poruszono również problem wykorzystania środków dydaktycznych podczas egzaminów zewnętrznych. Goście z Czech przedstawili jak wyglądają u nich zmiany w nauczaniu historii oraz wyniki europejskich badań porównawczych świadomości historycznej „Młodzież i historia” w Republice Czeskiej.

Obrady sekcji II, którym przewodniczyli doc. Ph dr Frantisek Capka, o. Eugeniusz Grzywacz SP oraz dr Kazimierz Puchowski skupiły się wokół problematyki działalności szkół pijarskich w Polsce oraz na terenie Czech, Moraw i Słowacji. Poruszano podczas niej tematykę różnorodnych form działalności oświatowej i kulturalnej pijarów, odnosząc ją zarówno do szkół pijarskich, ich wychowanków, jak też dokonań wybranych przedstawicieli zakonu.

Trzecia sekcja, obradami której kierowali: prof. Czesław Nowarski, prof. Wiesław Jamrożek oraz prof. Adam Suchoński zajęła się zarówno problematyką reformy edukacji, jak i podręczników historii - w tym kontrowersjami dotyczącymi europejskiego podręcznika do nauczania historii. Przedstawiono zmiany w świadomości historycznej młodzieży. Zajęto się także kwestią integracji międzyprzedmiotowej oraz koncepcjami wykorzystania edukacji regionalnej.

Uzupełnieniem obrad była wycieczka przygotowana przez organizatorów. Podczas niej uczestnicy konferencji odwiedzili zamek w Janowcu nad Wisłą, gdzie mieli okazję poznać jego przeszłość i eksponaty tamtejszego muzeum.

Trzeci dzień obrad uczestnicy rozpoczęli $w$ dwóch sekcjach. Pierwsza $z$ nich pod przewodnictwem dr Mirosławy Bednarzak-Libery, dr Barbary Tarnowskiej i dr. Kamila Stepanka kontynuowała problematykę sekcji pierwszej z poprzedniego dnia, skupiając się na sprawach związanych $\mathrm{z}$ reformą edukacji i oczekiwaniami stawianymi przed edukacją 
historyczną i obywatelską. Szczególną uwagę poświęcono problemowi wiedzy i umiejętności ucznia oraz zagadnieniom związanym z działalnością wychowawczą szkoły.

Sekcja II, której przewodniczyli prof. Adam Winiarz, prof. Roman Pelczar, ks. prof. Edward Walewander, kontynuując problematykę działalności oświatowej zakonu pijarów, zajęła się tradycjami nauczania zakonu. Podczas jej obrad odniesiono się do programu edukacyjnego Stanisława Konarskiego na tle współczesnych teorii pedagogicznych. Przedstawiono wychowanie dziewcząt w ujęciu ks. A.M. Prokopowicza, wpływ szkół pijarskich na szkoły parafialne oraz organizację $\mathrm{i}$ funkcjonowanie szkolnictwa pijarskiego na centralnych ziemiach polskich w połowie XIX w.

$\mathrm{Na}$ zakończenie konferencji dokonano jej podsumowania wskazując, że tematyka skupiała się wokół spraw związanych zarówno z działalnością edukacyjną zakonu pijarów, jak i problemów współczesnej dydaktyki. Liczny udział w konferencji osób zajmujących się przeszłością zakonu pijarów i jego rolą pozwolił na wymianę opinii i doświadczeń związanych $\mathrm{z}$ badaniami $\mathrm{w}$ tych dziedzinach. Poruszano podczas niej tematykę związaną z wkładem polskich pijarów w rozwój polskiej oświaty, jak też kultury i sztuki. Udział gości zagranicznych pozwolił na poszerzenie jej o podobne kwestie dotyczące działalności zakonu pijarów na terenie Czech i Słowacji. W trakcie obrad podjęto próbę omówienia skutków ostatniej reformy polskiej oświaty, szczególnie w odniesieniu do nauczania historii, dokonując porównania założeń reformy $\mathbf{z}$ ich realizacją.

Organizatorzy, dziękując uczestnikom konferencji, zapowiedzieli publikację referatów.

Dariusz Szewczuk

\section{Konferencja naukowa nt. „Opieka nad dzieckiem w Polsce - trady- cja i współczesność", 23 października 2007}

W dniu 23 października 2007 r. w murach Pogotowia Opiekuńczego w Gdańsku odbyła się konferencja naukowa nt. „Opieka nad dzieckiem w Polsce - tradycja i współczesność". Konferencję zorganizował Zakład Historii Nauki, Oświaty i Wychowania Instytutu Pedagogiki Uniwersytetu Gdańskiego oraz Pogotowie Opiekuńcze im. Karola Olgierda Borchardta w Gdańsku. Celem konferencji było przybliżenie polskich tradycji w zakresie opieki nad dzieckiem oraz podjęcie dyskusji na temat współczesnego systemu instytucjonalnej opieki nad najmłodszymi członkami społeczeństwa i kierunkami jego przeobrażeń. Ponadto zamierzeniem organizatorów było uświetnienie obchodów 60-lecia Pogotowia Opiekuńczego w Gdańsku, które jest jedną z najstarszych placówek opiekuńczych $\mathrm{w}$ tym mieście. Problematyka zaproponowana przez organizatorów skłoniła do przybycia na konferencję pracowników naukowo-dydaktycznych Uniwersytetu Gdańskiego, Akademii Pomorskiej w Słupsku oraz Kolegium Karkonoskiego w Jeleniej Górze, a także byłych i obecnych pracowników Pogotowia Opiekuńczego w Gdańsku oraz jego dobroczyńców.

Zebranych na konferencji gości w imieniu organizatorów uroczyście przywitali: dr Andrzej Kołakowski z Uniwersytetu Gdańskiego oraz mgr Grzegorz Barczewski - dyrek- 